DOROTA KIELAK

Instytut Filologii Polskiej

Uniwersytet Kardynała Stefana Wyszyńskiego w Warszawie

\title{
PARADOKSY MŁODOPOLSKIEJ ALEGORII
}

Słowa kluczowe: alegoria, alegoreza, rzeźba, powieść popularna, Młoda Polska

Keywords: allegory, allegoresis, sculpture, popular novel, the Young Poland movement

1.

W świadomości krytyków i historyków literatury zakorzeniło się przekonanie o tym, że artyści i pisarze przełomu XIX i XX wieku w zdecydowany sposób odrzucili alegorię na rzecz symbolu, tę pierwszą traktując jako środek wyrazu „martwy, jednostronny, niezdolny przemówić do wyobraźni”․ Do grona tych, którzy alegorii przeciwstawiali symbol, należeli m.in. Zenon Przesmycki (Miriam) oraz Ignacy Matuszewski. Ten ostatni pisał np.:

Alegoria idzie od świata abstrakcyjnego do świata konkretnego, czyli materializuje ideę, symbol chwyta w sposób syntetyczny i intuicyjny ideę i jej obraz. W alegorii widzimy następstwo dwóch żywiołów, czyli analizę: w symbolu jest współczesność, czyli synteza²

Trzeba jednak pamiętać, że w polskiej dziewiętnastowiecznej świadomości - jak pisze Janina Abramowska - dość nikłe odbicie miała dyskusja terminologiczna, różnicująca pojęcie alegorii i symbolu - dyskusja przebiegająca wyraziście w kulturze europejskiej ${ }^{3}$. To natomiast sprawiło, że w literaturze polskiej symbol - w sposób paradoksalny i niejako wbrew deklarowanym intencjom odróżnienia go od alegorii - „funkcjonuje niejednokrotnie nadal jako synonim

${ }^{1}$ Julian Krzyżanowski, „Alegoria w prądach romantycznych”, Przegląd Humanistyczny, no. 5 (1962): 4.

${ }^{2}$ Ignacy Matuszewski, Słowacki i nowa sztuka (modernizm). Twórczość Słowackiego w świetle pogląów estetyki nowoczesnej. Studium krytyczno-porównawcze, ed. Samuel Sandler (Warszawa: PIW, 1965), 254. Cyt. za: Maria Podraza-Kwiatkowska, Symbolizm i symbolika w poezji Młodej Polski (Kraków: Towarzystwo Autorów i Wydawców Prac Naukowych „Universitas”, 1994), 37.

${ }^{3}$ Vide Janina Abramowska, „Rehabilitacja alegorii”, in Alegoria, ed. Janina Abramowska (Gdańsk: słowo/obraz terytoria, 2003), 14. 
alegorii” ${ }^{4}$. Niezależnie też od tego, że - jak stwierdza dalej badaczka - temperatura sporu o różnice między symbolem a alegorią zdecydowanie wzrasta na przełomie wieków, to

praktyka twórcza [symbolistów - uzupełn. D.K.], zwłaszcza u słabszych poetów (także malarzy), sprowadza się jednak do tworzenia obrazów „dziwnych”, a świeższych o tyle, że jednorazowych lub zaczerpniętych z mniej znanych, legendowych pokładów tradycji północnoeuropejskich (Graal, jednorożec) i orientalnych ${ }^{5}$.

Jak bowiem przekonuje Paul de Man, powołując się na zdanie Hansa Gadamera, mimo że „podłożem dziewiętnastowiecznej estetyki [...] była wolność umysłu obdarzonego mocą symbolizowania”, to jednak owa „aktywność symbolistyczna"7 wyraźnie zespala się z ,pewną tradycją mitologiczną i alegoryczną, która przetrwała"8.

Julian Krzyżanowski w tej młodopolskiej - niekonsekwentnej, jak się okazuje - batalii o uznanie wyższości symbolu nad alegorią dostrzega nie tyle jednak brak spójności, co naturalny dla epoki proces „pogłębienia sensu alegorii, awansowanej do stanowiska symbolu" ". Oceniając młodopolskie dyskusje o znaczeniu i randze symbolu w sztuce z perspektywy prowadzonego równolegle dyskursu na temat romantycznych korzeni modernistycznej sztuki, czyli na temat znaczenia dorobku Juliusza Słowackiego i Cypriana Norwida w kształtowaniu się literackiej wrażliwości na przełomie XIX i XX wieku, wskazuje na szczególnego rodzaju paradoks. Polega on - jego zdaniem - na tym, że młodopolanie, zainspirowani symbolistyczną ideą formy, poszukiwali jej również w twórczości tych, dla których istotnym środkiem artystycznego wyrazu była alegoria. Transponowanie fascynacji symbolizmem na twórczość Słowackiego i Norwida było w efekcie zgodą na alegorię. „,...] neoromantyczna droga od alegorii do symbolu, bo tak właściwie sprawę ówczesnego symbolu rozumieć należy, polegałaby na wzmożeniu wymowy artystycznej czy siły ekspresyjnej alegorii przy pomocy odpowiednich zabiegów kompozycyjnych"10. Na poparcie swojej tezy Krzyżanowski przypomina takie utwory, jak: Na Aniot Pański bija dzwony Kazimierza Przerwy-Tetmajera, Hymny Jana Kasprowicza, Sny o potędze Leopolda Staffa, zwracając uwagę na obecność w nich „zagadkowej postaci o konturach ludzkich” ${ }^{11}$, eksponowanej na tle „obrazów budzących rozległe skojarzenia wzrokowe, słuchowe lub jedne

\footnotetext{
${ }^{4}$ Ibidem.

${ }^{5}$ Ibidem, 14-15. Vide też Maria Podraza-Kwiatkowska, Symbolizm i symbolika..., 20.

${ }^{6}$ Paul de Man, „Retoryka czasowości”, trans. Andrzej Sosnowski, in Alegoria, 147.

${ }^{7}$ Ibidem.

${ }^{8}$ Ibidem.

${ }^{9}$ Julian Krzyżanowski, „Alegoria w prądach romantycznych”, 4.

${ }^{10}$ Ibidem.

${ }^{11}$ Ibidem.
} 
i drugie, zwłaszcza obrazów przyrody" ${ }^{12}$, sprawiających, że czytelnik był przekonany, iż ogląda symbole najczystszej wody ${ }^{13}$. Próba scalenia prądu powstałego na gruncie kultury francuskiej z rodzimą tradycją sprawiła, według Krzyżanowskiego, że

\begin{abstract}
stara alegoria odżyła i zajaśniała tymi wszystkimi urokami, którymi wabiła pokolenia twórców działających w okresach romantycznych. Że uroki te wzbogaciły się mnóstwem pomysłów nowych, konstruowanych bardzo nieraz precyzyjnie. Że wreszcie przez osłabienie konwencjonalnego symbolu-emblematu alegoria neoromantyczna nabrała zagadkowej wieloznaczności, przemawiającej do wyobraźni czytelnika, tak że niejednokrotnie otrzymywała charakter symbolu w nowym znaczeniu tego wyrazu ${ }^{14}$.
\end{abstract}

W świetle refleksji wspomnianego badacza to właśnie romantyczna alegoria zaspokajała młodopolskie potrzeby w zakresie formy artystycznej, tworząc grunt dla symbolistycznych inspiracji, ale nie ustępując im do końca. Alegoria ta - jak określał ją cytowany wyżej Matuszewski - „materializowała idee”, a jednocześnie odznaczała się „nastrojowym rozmyciem”" mitologiczną czy też legendową proweniencję.

\title{
2.
}

Ciekawego materiału do rozważań o modernistycznej alegorii i jej miejscu w estetyce na początku XX wieku dostarczają utwory prozatorskie, w których pojawiają się rzeźby i rzeźbiarze. W utworach, w których ważną rolę odgrywają rzeźbiarskie dzieła sztuki, obarczone funkcją materializowania określonych idei, bardzo dobrze widać ów proces przezwyciężania alegorii na rzecz symbolu. Warto tu przytoczyć jako pierwsze opowiadanie Stefana Żeromskiego Pavoncello, w którym taką alegoryczną funkcję pełni marmurowa rzeźba tancerki, mogąca być kopią hellenistycznej rzeźby przedstawiającej Venus ${ }^{16}$. Jej opis pojawia się po raz pierwszy w znaczącym momencie, kiedy pozbawiony pracy muzyk, spędzając całe dnie w salach Muzeum Watykańskiego, staje przed marmurową figurą, przy której chwilę później dostrzeże piękną Rosjankę - jak się niebawem okaże - największą miłość swojego życia. Figura ta jest w tym kontekście zapowiedzią mającego się wkrótce nawiązać romansu z tajemniczą pięknością, ale przede wszystkim materializuje ideę kobiecości, jaką miał w swej wyobraźni Ernesto Fosca.

\footnotetext{
${ }^{12}$ Ibidem.

${ }^{13}$ Ibidem, 14. Zdanie to podkreśla jako słuszne Janina Abramowska, op. cit., 15.

${ }^{14}$ Julian Krzyżanowski, „Alegoria w prądach romantycznych”, 16.

${ }^{15}$ Określenie Janiny Abramowskiej - Janina Abramowska, op. cit., 15.

${ }^{16} \mathrm{Na}$ temat możliwości zidentyfikowania tej rzeźby vide Muzeum $w$ literaturze polskiego modernizmu. Antologia, ed. Dorota Kielak, not. Dorota Kielak, Małgorzata Wrześniak (Kraków: Towarzystwo Autorów i Prac Naukowych „Universitas”, 2016), 137 (not. 7 in Stefan Żeromski, Pavoncello
} [fragmenty]). 
Była bowiem w tym posągu zawarta jak gdyby suma kobiecości, obraz tego, co we wszystkich kobietach, razem wziętych, jest ich najsubtelniejszym urokiem, tajemniczym zapachem, pięknością najistotniejszą, mocą sekretną, odurzającą jako zaklęcie, które niweczy wolę. Marzenia męskiej młodości, wszechwładnie i ze wszech stron, zawsze i w każdym swoim objawie ogarnięte przez kształt kobiecy, przesycone nim od początku swego do końca, wcieliły się w bryłę tego marmuru. Nie było w tym artystycznej kontemplacji dzieła sztuki, lecz zawrót głowy, duszenie w sercu, nieświadomość w myślach i szał nerwów ${ }^{17}$.

Tak jak Matuszewski pisał, że „alegoria idzie od świata abstrakcyjnego do wiata konkretnego", tak też Żeromski opisuje figurę tancerki jako kształt, w którym bohater znalazł upostaciowanie swoich wyobrażeń na temat kobiecości. Warto też zauważyć, że podobną funkcję pełni rzeźba Wenus w powieściowej biografii doktora Judyma z Ludzi bezdomnych. Będzie ona patronować pierwszemu spotkaniu bohatera z Joasią Podborską i zapowiadać ich romans. W jej obliczu materializują się przeżycia zapowiadające duchową wspólnotę bohaterów ${ }^{18}$.

Szczególnie ważne stają się w tym kontekście powieści z obiegu popularnego, ponieważ - po pierwsze, zarówno rozważania na temat literatury popularnej, jak i alegorii, wymagają wyeksponowania podobnych kategorii ${ }^{19}$. Po drugie - poczytność tychże powieści, a tym samym ich miejsce w świadomości kulturowej przełomu XIX i XX wieku ${ }^{20}$, sprawia, że refleksja o zastosowanej w nich alegorii pozwala wnioskować o mechanizmach świadomość tę kształtujących. I tak w powieści Kazimierza Przerwy-Tetmajera Aniot śmierci ${ }^{21}$ rzeźba pod takim

${ }^{17}$ Stefan Żeromski, „Pavoncello”, in idem, Pisma zebrane, ed. Zbigniew Goliński, vol. 4: Sen o szpadzie, Pomytki i inne utwory epickie, ed. Zdzisław Jerzy Adamczyk (Warszawa: Czytelnik, 1990), 163.

${ }^{18}$ Vide Magdalena Popiel, Oblicza wzniostości. Estetyka powieści młodopolskiej (Kraków: Towarzystwo Autorów i Wydawców Prac Naukowych „Universitas”, 1999), 103-105.

${ }^{19}$ Jacek Kolbuszewski pisze, że „literaturę popularną niejako «stwarza» jej odbiorca-czytelnik” [Jacek Kolbuszewski, Od Pigalle po Kresy. Krajobrazy literatury popularnej (Wrocław: Wydawnictwo Uniwersytetu Wrocławskiego, 1994), 12], że „w rozważaniach o literaturze popularnej nie da się uciec od owej kategorii odbiorcy, «społecznie określonego czytelnika wirtualnego» i «społecznie określonego czytelnika rzeczywistego»” (ibidem, 14). Morton F. Bloomfield przekonuje natomiast, że „alegorią nazwiemy to, co ustanowione zostało dzięki interpretacji - lub sam proces interpretacyjny” (Morton W. Bloomfield, „Alegoria jako interpretacja”, trans. Zdzisław Łapiński, in Alegoria, 53), wskazując tym samym na ważność perspektywy odbioru w refleksji o alegorii.

${ }^{20}$ Vide e.g. Jacek Kolbuszewski, op. cit., 11. Cf. Anna Martuszewska, „Ta trzecia”. Problemy literatury popularnej (Gdańsk: Wydawnictwo Uniwersytetu Gdańskiego, 1997), 11-14. Na temat literatury popularnej jako istotnego składnika kultury nowoczesnej cf. Włodzimierz Bolecki, „Kilka uwag o periodyzacji literatury polskiej (Wstęp)”, in idem, Modalności modernizmu. Studia. Analizy. Interpretacje (Warszawa: Instytut Badań Literackich PAN et Wydawnictwo Fundacja Humanistyczna, 2012), 11.

${ }^{21}$ Omawiane w tym szkicu powieści Kazimierza Przerwy-Tetmajera oraz Tadeusza Jaroszyńskiego były przedmiotem mojej refleksji w książce Figury kryzysu. Rzeźba w młodopolskiej powieści o artyście (Warszawa: Wydawnictwo Uniwersytetu Kardynała Stefana Wyszyńskiego, 2007) i choć refleksja ta nie została sproblematyzowana pod kątem alegorii, to w książce tej znajdują się niejednokrotnie istotne dopełnienia niniejszych rozważań. 
samym tytułem, którą wykuwa z marmuru Rdzawicz, miała unaocznić zło tkwiące w kobiecej naturze, odkryte pod wpływem zawodu miłosnego bohatera porzuconego przez wiarołomną narzeczoną. Jej projekt powstawał pod wpływem chęci obnażenia bezwzględnej femme fatale, dlatego też przedstawiała ona leżącego na ziemi mężczyznę, którego piersi deptała kobieta „odsłaniająca z draperii nagi przód ciała” 22 i sportretowana w „ruchu wyzywającym hetery”23. Wreszcie w utworze Tadeusza Jaroszyńskiego tytułowa Chimera miała wyobrażać kobietę-olbrzymkę duszącą artystę monstrualnym kolanem i miała być alegorią losu artysty ${ }^{24}$. Przy czym dzieło to - w przeciwieństwie do Anioła śmierci nigdy nie zostało sfinalizowane, jako wciąż doskonalone znajdowało się w procesie nieustającego tworzenia ${ }^{25}$.

Rzeźbiarskie kompozycje - $\mathrm{z}$ jednej strony - tworzyły materialną formę określonych idei, z drugiej natomiast - zgodnie z tym, co pisał o młodopolskiej alegorii Krzyżanowski, umieszczone zostały w specyficznej nastrojowej aurze. Ich „nastrojowe rozmycie” osiągnięte zostało poprzez nawiązanie do mitologii. W powieści Jaroszyńskiego rzeźba o tytule Chimera nawiązuje do mitologii greckiej, dodatkowo też - jako ostatecznie nieukończona - pojawia się cały czas w halucynacyjnych wizjach artysty, w których zaciera się realność jej kształtów ${ }^{26}$. W oczywisty sposób do mitologii odsyła rzeźba Wenus z pierwszych kart Ludzi bezdomnych Żeromskiego, stając się „odpowiednikiem apolińskiej wyroczni, która mądrością obejmuje przestrzeń i czas, zło i dobro, szczęście i ból"27. W jego opowiadaniu Pavoncello „nastrojowe rozmycie” rzeźby osiągnięte zostaje natomiast poprzez nawiązanie do mitu Pigmaliona. Fosca widzi w marmurowych kształtach greckiej tancerki potencjał życia, który zmaterializuje się w osobie pięknej Rosjanki.

Ernesto Fosca zmrużonymi oczyma przypatrywał się uwodzicielce sprzed tysięcy lat i poświstywał na jej chwałę hymn najbardziej wzniosły, wymuszony przez namiętny, młodzieńczy zachwyt. Nie zdziwiłby się był wcale, gdyby ta driada, tak radośnie pląsająca, zbiegła ze swego marmurowego tronu i w skokach doskonale pięknych, nieomylnie natchnionych, porywających aż do szału, obiegła ciche schronienie, gdzie są uczczone prace przedwiecznych artystów. Powiódł oczyma

${ }^{22}$ Kazimierz Przerwa-Tetmajer, Anioł śmierci. Romans (Kraków: Nakład Księgarni J. Czarneckiego, 1918), 230.

${ }^{23}$ Ibidem.

${ }^{24}$ Vide Tadeusz Jaroszyński, Chimera. Powieść z życia artystów, introd. Zdzisław Dębicki (Warszawa: Druk Józefa Sikorskiego, 1905), vol. 1, 54-55.

${ }^{25}$ Warto oczywiście zauważyć, że we wskazanych utworach z obiegu popularnego ujawnia się mizoginiczna postawa artysty, który w swym rzeźbiarskim dziele sztuki zawiera całokształt przekonań na temat kobiety traktowanej jako femme fatale. Jest to oczywiście wątek, którego rozwinięcie nie mieści się w granicach wyznaczonych dla tego szkicu, a który może stać się podstawą odrębnej refleksji.

${ }^{26}$ Vide Tadeusz Jaroszyński, op. cit., 26-27.

${ }^{27}$ Magdalena Popiel, op. cit., 104. 
dokoła drogi jej domniemanych polotów - i wzdrygnął się ze zdumienia. Niedaleko od miejsca jego adoracji stała przecudna żywa driada. Podobnie jak ona patrzyła na posąg, a podobnie jak posąg uśmiechała się radośnie ${ }^{28}$.

Kształty rzeźby w znaczący sposób zlewają się w wyobraźni bohatera z żywą kobietą, o której chwilę później mówi się zresztą, że miała „dłoń wypieszczoną, białą, o palcach jak gdyby rzeźbionych w przezroczystym marmurze" ${ }^{29}$. W ten sposób piękna Zinajda w tej grze wyobraźni staje się - jak Galatea - ożywioną postacią marmurowej tancerki.

Rzeźbiarskie dzieła materializują w wymienionych utworach określone idee, charakteryzując się przy tym „nastrojowym rozmyciem”, jednak - co znamienne - nie tylko to oddala je od alegorii, ale to, że część $\mathrm{z}$ tych dzieł okazuje się nietrwała. Bohaterowie powieści Tetmajera i Jaroszyńskiego sami niszczą swoje alegoryczne kreacje. Rdzawicz rozbija młotem własną rzeźbę, kiedy uświadamia sobie, że jej znaczenie jest zbyt wyraźne i wywoła środowiskowy skandal. Ordon z powieści Jaroszyńskiego rozbija swoją niedokończoną jeszcze Chimerę, bo materializowane przez nią treści niewystarczająco współgrały z jej formą. Klęska bohaterów w tworzeniu rzeźbiarskiej alegorii wydaje się przy tym być odbiciem przemian, którym poddawała się estetyka modernistycznej rzeźby na początku XX wieku. Alegoria na znaczeniu buduje swoją tożsamość, znaczenie jest podstawową jej wartością ${ }^{30}$. Tymczasem rzeźbiarz z przełomu XIX i XX wieku - jak pisze Maria Potocka - choć niejednokrotnie „popadał w dziwne sentymentalne zależności, tworząc literacko-symboliczne konstrukcje lub erotyczno-boskie kombinacje" ${ }^{31}$, to jednak czynił to zawsze kosztem rezygnacji z wartości, jaką było znaczenie. Potocka, opisując proces tworzenia się nowych tendencji w sztuce przełomu XIX i XX wieku na przykładzie rzeźby pomnikowej, podkreśla, że jest on integralnie związany ze zjawiskiem „kurczenia się tematu w konfrontacji z siłą problematyki rzeźbiarskiej” ${ }^{2}$, a więc rezygnacji ze znaczenia:

Ciekawym przykładem wymykania się i zanikania tematu są nagrobki. [...] Rzecz sprowadza się do ruchu, pozycji i ich kontekstów, które razem dążą do powołania symbolu p o p r z e z atmosferę, a nie poprzez znaczenie. Żeby taką delikatność uzyskać, trzeba było wycofać wszelkie bezpośrednie znaczenia, gdyż ich siła byłaby przytłaczająca [podkreśl. D.K.] ${ }^{33}$.

${ }^{28}$ Stefan Żeromski, „Pavoncello”, 164.

${ }^{29}$ Ibidem, 165.

${ }^{30}$ Cf. Hans-Georg Gadamer, Prawda i metoda. Zarys hermeneutyki filozoficznej, trans. Bogdan Baran (Kraków: „Inter Esse”, 1993), 98. Cyt. za: Paul de Man, „Retoryka czasowości”, 144.

${ }^{31}$ Maria Anna Potocka, Rzeźba. Dzieje teoretyczne (Kraków: Wydawnictwo Baran i Suszczyński, 2002), 252.

${ }^{32}$ Ibidem, 256.

${ }^{33}$ Ibidem, 257-258. 
Rzeźbiarze rezygnowali z wyrażania określonych treści, a skupiali się na formalnych eksperymentach. Tylko „głębokie odczucie materialnej, fizycznej istoty rzeźby” ${ }^{34}$ pozwalało na wydobycie jej „silnego i nieopisanego znaczenia poprzez naruszanie formy, poprzez wydobywanie jej «jedynej» racji” ${ }^{35}$.

Porażka artystyczna pojawiała się, kiedy [artysta - D.K.] próbował świadomie przekazać jakąś treść. W takich momentach forma się na niego obrażała, nabierała usztywnionej grzeczności i milczała, niechętna wszystkiemu, łącznie z tym, co przekazywała. Dzieło ulegało zniszczeniu przy całkiem niewinnym celu ${ }^{36}$.

Można powiedzieć, że tworzenie znaczeń w rzeźbie sprzęgnięte zostało na przełomie XIX i XX wieku ze świadomością wszystkich możliwości eksperymentowania na formie, które pozbawiało tym samym rzeźbiarską kompozycję zdolności do materializowania idei. Nie tyle rzeźbienie „na temat”, co wyczucie kształtu i materiału, a także możliwości przekraczania ograniczeń wynikających z tworzywa, sprzyjało wydobywaniu z rzeźby jej treści.

Najwyraźniejszym sygnałem uwalniania rzeźby od jej alegorycznego znaczenia było docenienie „potencjału rzeźby niepełnej” ${ }^{37}$, rzeźby okaleczonej na podobieństwo starożytnych dzieł sztuki, odnajdywanych we fragmentach jako niekompletne, uszkodzone. Nie bez powodu np. Zygmunt Wasilewski mistrzostwa rzeźbiarskiego warsztatu Antoniego Kurzawy upatrywał we fragmentach rzeźb, które pozostały po tym, jak artysta rozbił swoją kompozycję zatytułowaną Mickiewicz budzacy geniusza poezji oraz Siewca. Choć sam gest rozbijania przez twórcę własnego dzieła funkcjonalizuje się znaczeniowo w refleksji na temat tragizmu artysty, refleksji czyniącej z niego ikonę sprzeciwu wobec braku społecznej wrażliwości na sztukę, niezgody na mieszczańskie gusta ${ }^{38}$, to dokonana przez krytyka kwalifikacja ocalałych fragmentów rzeźb bardzo wyraźnie sprzyja postawionej wyżej tezie.

Do najwybitniejszych dzieł Kurzawy, obok Mickiewicza, należy wspomniany wyżej Chłop-siewca, zwłaszcza jego ręka prawa. Nad tą ręką długo pracował. Wskutek skłonności artysty do symbolizowania idei, dzięki myślicielskiemu usposobieniu jego, ręka ta nabrała w jego oczach prawie mistycznego znaczenia; najwidoczniej pragnął ucieleśnić w niej mozół pracy ludowej. Ręki takiej nie powstydziłby się Michał Anioł. [...]

[...] Kurzawa widać dobrze znał Mickiewicza z wizerunków, ale było w niej coś więcej nad portret: artysta zaklął w niej swój ideał Mickiewicza. Głowa w rysunku - jak płomień, jakby wichrowi poddana, a na jej obliczu rzeźbiarz wypisał wyrazami rzeźbiarskimi wszystko, co o zawartości tej głowy myślał. Stopił te znamiona w jakiś je den dziwny wy raz, którego

\footnotetext{
${ }^{34}$ Ibidem, 253.

${ }^{35}$ Ibidem.

${ }^{36}$ Ibidem.

${ }^{37}$ Ibidem, 264.

${ }^{38}$ Cf. Dorota Kielak, Figury kryzysu, 232-235.
} 
widz nie jest w stanie rozłożyć na pierwiastki i doznaje pewnego n i e pokoju, jakby pod wzrokiem sfinksa [podkreśl. D.K.] ${ }^{39}$.

Dla krytyka właśnie zachowane „ułomki” rzeźb, tzn. głowa Mickiewicza z kompozycji przygotowanej na konkurs na pomnik wieszcza z okazji rocznicy stulecia jego urodzin ${ }^{40}$ oraz ręka chłopa „siewcy” emanują trudną do określenia emocjonalną aurą. Właśnie te fragmenty - według Wasilewskiego - najlepiej świadczą o zdolności artysty do „symbolizowania idei”, czyli sugerowania treści poprzez zabiegi formalne.

Tak jak rzeźbiarz, o którym cytowana wcześniej Potocka pisała jako o artyście naruszającym płynność kompozycji rzeźbiarskiej, by - „sprawdzając, jak głęboko w rzeźbie znajduje się rzeźba" ${ }^{41}$ - zredukować przede wszystkim jej temat ${ }^{42}$, tak też w literaturze za pomocą elementów rzeźby eksponowano proces rezygnacji z uznawania jej alegorycznego potencjału. Bardzo dobrze widać to np. w opowiadaniu Mariana Gawalewicza Synowie Laokoona, w którym bohater oburza się na myśl o rekonstruowaniu zdeformowanych antycznych dzieł sztuki, w ich brakach właśnie dostrzegając sugestywność treści.

[...] gorszyły go pomysły pigmejów, gramolących się ku boskim ramionom Wenery Milońskiej, aby dolepić olimpijskiej kalece odkruszone ręce.

Oburzał się na niezręcznych rekonstruktorów, którzy wysilali swe mózgi, by odgadnąć tajemnicę jej ruchu i chcieli z posągowej, czystej i wspaniałej w swej piękności bogini, zrobić jakąś zalotnicę nowszych czasów, przyglądającą się swoim wdziękom w zwierciadle polerowanej tarczy, lub kazali drugim ramieniem obejmować jej Aresa, jak kochance romansującej w oczach całego tłumu ze zbrojnym bogiem wojny.

Przeczucie mu mówiło inaczej; jego zmysł estetyczny raziły takie poziome pomysły uzupełnienia klasycznego posągu, któremu przypadek dodał jakiejś melancholijnej poezji i symboliki $^{43}$.

Aprobatywne zainteresowanie literatury rzeźbą „ułomną”, zdeformowaną i poddaną procesowi destrukcji, bardzo wyraźnie pokazuje, że nie szukano w niej alegorii, nie oczekiwano od niej wyraźnie materializowanych znaczeń. Alegoria w młodopolskiej świadomości traciła swoją legitymację, odbierano jej możliwość tworzenia znaczeń, co najwyraźniej widać w dramacie Stanisława Wyspiańskiego Akropolis. W utworze tym autor za pomocą Pigmalionowego rodem gestu ożywiania rzeźb z wawelskiej katedry obnażył wewnętrzną niespójność

${ }^{39}$ Zygmunt Wasilewski, „Antoni Kurzawa (ur. 1843, zm. 1891). Wspomnienie pozgonne”, in idem, Od romantyków do Kasprowicza. Studia i szkice literackie (Lwów: Towarzystwo Wydawnicze, 1907), 264-265.

${ }^{40}$ Vide Dorota Kielak, Figury kryzysu, 84-99.

${ }^{41}$ Maria Anna Potocka, Rzeźba, 254.

${ }^{42}$ Ibidem.

${ }^{43}$ Marian Gawalewicz, „Synowie Laokoona”, in idem, Dwie baśnie. I. Synowie Laokoona (ze snów na jawie), II. Jak się głupi Janek kochał... (wierutna bajka) (Warszawa: [s.n.], 1907), 19. 
między treścią a formą rzeźbiarskich kreacji, tej ostatniej przyznając ostateczną wartość. Szczególnie klasycystycznym rzeźbom-alegoriom odebrał prawo do miana sztuki, wykazując ich artystyczną niezborność, która polegała na nieadekwatności materializowanych przez nie wzniosłych idei do jej zmysłowych kształtów ${ }^{44}$.

3.

Nie dziwi w tym kontekście fakt, że w wymienionych wcześniej utworach rzeźbiarska alegoria - zinterpretowana właśnie jako ta, która traci zdolność budowania znaczeń - tak łatwo poddawała się gestowi destrukcji. Jej znaczenia okazywały się bowiem zbyt dosłowne, a czasem po prostu nieprawdziwe. W opowiadaniu Żeromskiego idea kobiecości, którą materializowała figura greckiej tancerki, okazała się przede wszystkim złudna. Piękna Rosjanka, która była marzeniem męskiej duszy muzyka, okazała się w konsekwencji kobietą poszukującą w dość wyrachowany sposób ojca dla upragnionego przez siebie i swojego męża dziecka. W Ludziach bezdomnych posąg Wenus - jako „roztaczającej przed bohaterem horyzont szczęścia" ${ }^{45}$ - w wyniku powieściowych zdarzeń stanie się raczej znakiem „antycznego fatum” ${ }^{46}$ skazującego Judyma i Joasię na cierpienie. Młodopolscy pisarze przekonywali, iż rzeźbiarska alegoria tworzy iluzje znaczeń, fałszuje rzeczywistość, zbyt dosłownie formułuje swoje sensy, mając jednocześnie potencjał do tego, by oddziaływać siłą swojej rzeźbiarskiej formy, by wpływać na wrażliwość odbiorcy sugestywnością swoich kształtów. Dlatego też dyskredytowaniu alegorycznej funkcji rzeźb w omawianych powieściach towarzyszyło wykorzystywanie opisywanych dzieł sztuki jako nośników kluczowych znaczeń wspomnianych powieści. Dzieła te - choć pozbawione funkcji materializowania idei, które były ważne dla bohaterów powieści - tworzą zasadę kompozycyjną wymienionych utworów. Należałoby mówić w tym miejscu już nie tyle o alegorii, ile o alegorezie ${ }^{47}$. Opisane rzeźby, które miały materializować idee bohaterów, zdecydowanie lepiej pełnią funkcję prefiguracji ich losów. Nie bez powodu np. figura greckiej tancerki w opowiadaniu Żeromskiego opisywana jest nie tylko wtedy, gdy Pavoncello rozpoczyna romans z piękną Rosjanką, lecz także wówczas, gdy historia nieszczęśliwej miłości dobiegnie swojego finału. Wtedy, gdy Pavoncello zda sobie sprawę, że Zinajda prawdopodobnie straciła życie podczas rosyjskiej rewolucji, znów pójdzie do Muzeum Watykańskiego, by „modlić” się do figury o życie dla swojej ukochanej.

${ }^{44}$ Vide Wojciech Bałus, „Ożywianie posągów. Glosa do Akropolis”, in Stanisław Wyspiański, studium artysty. Materiały z sesji naukowej na Uniwersytecie Jagiellońskim 7-9 czerwca 1995, ed. Ewa Miodońska-Bookes (Kraków: Towarzystwo Autorów i Prac Naukowych „Universitas”, 1996), 177.

${ }^{45}$ Magdalena Popiel, op. cit., 105.

${ }^{46}$ Ibidem, 104.

${ }^{47}$ Vide Janina Abramowska, op. cit., 6. 
Któregoś dnia rzymskiej wiosny same nogi poniosły go w progi Watykanu i same zaprowadziły przed posąg greckiej tancerki. Tak samo lekka, polotna, uśmiechnięta i szczęśliwa nosiła się w pląsach ponad falami czasów. W falach czasów przewalała się wojna i zalegał pokój, wybuchały rewolucje i srożyły się reakcje, przemijały posępne zabobony plemion i gasły jasne religie, wyśnione przez synów człowieczych.

Fosca płakał przed obliczem kamiennej tanecznicy i pytał się nieśmiertelnego jej wesela o los Zinaidy. Z oczyma zalanymi łzami, z załamanymi rękoma nadaremnie żebrał o łaskę odmiennej wieści ${ }^{48}$.

W scenie tej figura tancerki będzie już nie tylko materializacją idei kobiecości, ale przede wszystkim ucieleśnieniem życiowej tragedii bohatera tęskniącego za radością i pięknem miłości w świecie poddanym brutalnym prawom wojny $^{49}$. Fakt, że odniesienie do marmurowej figury w pewien sposób spina utwór, świadczy o tym, iż rzeźba ta określa perspektywę interpretacji opowiadania, projektuje alegoryczny styl jego lektury. Taka sama jest w Ludziach bezdomnych funkcja rzeźby Wenus z Milo, która - stając się „kompozycyjnie uwypuklonym składnikiem całego powieściowego świata" ${ }^{50}$ - wraz z zastępująca ją figurą rozdartej sosny tworzy klamrę kompozycyjną całego utworu ${ }^{51}$, otwierając jego interpretację w perspektywie rozważań o tragizmie i cierpieniu. Podobną funkcję mają rzeźby w przypomnianych wcześniej powieściach Jaroszyńskiego i Tetmajera ${ }^{52}$. W tej pierwszej scena śmierci bohatera - śmierci z powodu niemożności artystycznego spełnienia - urealnia niejako scenę z jego własnej kompozycji rzeźbiarskiej, w której twórcę zabija jego sztuka. Tytułowa rzeźba, nazwana Chimera, materializuje więc nie tylko idee artysty, lecz także i jego fabularne losy. Również Rdzawicz z powieści Tetmajera „wciela” się niejako w figurę wykutego przez siebie w marmurze mężczyzny, którego zabija kamienna femme fatale. Niszcząc bowiem swoją rzeźbę „doznał uczucia, jakby mu kto szpadą przeszył mózg, a potem jakby weń wpłynął strumień płonącej lawy. Zakręcił się, rozkrzyżowawszy ramiona cofnął $\mathrm{i}$ padł $\mathrm{w}$ tył na posąg uderzając $\mathrm{z}$ głuchym łoskotem czaszką o marmurowe nogi obnażającej się kobiety" ${ }^{53}$.

Fakt tak wyraźnego pod koniec powieści zespolenia rzeźby z losami artysty, a tym samym $z$ fabułą utworu, uświadamia, że mamy do czynienia $\mathrm{z}$ alegorią zdyskredytowaną w losach bohaterów, ale jednocześnie wyznaczającą sposób odczytania powieści. Alegoreza bowiem apeluje do wrażliwości odbiorcy w ustanawianiu znaczeń, pozwalając jednocześnie na ich zuniwersalizowanie ${ }^{54}$. Przy czym, warto podkreślić, że w tych dwóch wskazanych powieściach alegoreza

\footnotetext{
${ }^{48}$ Stefan Żeromski, op. cit., 214.

${ }^{49}$ Vide Dorota Kielak, Muzeum w literaturze...

${ }^{50}$ Magdalena Popiel, op. cit., 104.

${ }^{51}$ Vide ibidem, 106.

${ }^{52}$ Vide Dorota Kielak, Figury kryzysu, 340-342.

${ }^{53}$ Kazimierz Przerwa-Tetmajer, op. cit., 412.

${ }^{54}$ Vide Morton W. Bloomfield, op. cit., 57.
} 
tworzy się tylko i wyłącznie poprzez akt zniszczenia rzeźb, on bowiem znacząco dopełnia tragizm artystycznej biografii z przełomu XIX i XX wieku. Można więc powiedzieć, że - w paradoksalny sposób - dopiero zaprzeczenie artystycznej wartości alegorii pozwala uruchomić alegorezę, która mobilizuje do odkrywania znaczeń daleko wykraczających poza opisane w utworach historie. W ten sposób modernistyczne utwory, w których pojawiają się rzeźby-alegorie, nie tylko utwierdzają $\mathrm{w}$ tym procesie weryfikowania alegorii, ale też ujawniają sposób, w jaki ten proces się dokonuje.

\section{THE PARADOX OF THE YOUNG POLAND MOVEMENT ALLEGORY}

\section{Sum mary}

The present sketch traces the process of verifying allegory which takes place in the Young Poland prose, in which authors use the images of sculptures. The interpretation of Pavoncello, a story by Stefan Żeromski, Chimera, a novel by Tadeusz Jaroszyński and The Angel of Death by Kazimierz Przerwa-Tetmajer allows to put forward a thesis that the allegorical function of sculptural works of art which appear in the presented world is challenged, whereas allegory understood as the compositional principle of a work is strengthened. Verification of allegory for the benefit of allegoresis is done by challenging the 'semiogenic' function of allegory and at the same time by appreciating it for defining trails of interpretation and universalizing meanings. 